\title{
Economic and Social Aspects of Using Energy from PV and Solar Installations in Farmers' Households in the Podkarpackie Region
}

\author{
Ryszard Kata (D), Kazimierz Cyran, Sławomir Dybka, Małgorzata Lechwar and Rafał Pitera *(D)
}

Citation: Kata, R.; Cyran, K.; Dybka, S.; Lechwar, M.; Pitera, R. Economic and Social Aspects of Using Energy from PV and Solar Installations in Farmers' Households in the Podkarpackie Region. Energies 2021, 14, 3158. https://doi.org/10.3390/ en14113158

Academic Editor: Vincenzo Bianco

Received: 12 April 2021

Accepted: 24 May 2021

Published: 28 May 2021

Publisher's Note: MDPI stays neutral with regard to jurisdictional claims in published maps and institutional affiliations.

Copyright: (c) 2021 by the authors. Licensee MDPI, Basel, Switzerland. This article is an open access article distributed under the terms and conditions of the Creative Commons Attribution (CC BY) license (https:// creativecommons.org/licenses/by/ $4.0 /)$.
Institute of Economics and Finance, University of Rzeszow, ul. M. Ćwiklinskiej 2, 35-601 Rzeszów, Poland rdkata@ur.edu.pl (R.K.); kcyran@ur.edu.pl (K.C.); slawekd@ur.edu.pl (S.D.); lechwarm@ur.edu.pl (M.L.)

* Correspondence: rpitera@ur.edu.pl

\begin{abstract}
The growing energy needs of agriculture, the need to reduce the burning of fossil fuels, and, on the other hand, the increasing technical efficiency are contributing to the wider use of solar energy technology in agriculture. The aim of the article is to identify factors determining farmers' investments in solar photovoltaic and solar thermal installations for electricity and heat production, to establish the proportion between the consumption of such energy for the needs of the farmer's family and for the needs of the farm, and to identify the drivers of solar energy use in agricultural production. Empirical materials were collected through surveys of farmers conducted at the end of 2020 in south-eastern Poland, in the Podkarpackie region. It is a region characterized by significant land fragmentation. Producing energy from renewable sources can be an opportunity for farmers not only to reduce household expenses, but also to increase agricultural income. As a result, it can be a driver of sustainable agricultural development in the region. The article presents the most important economic and social determinants that stimulate the adoption of solar photovoltaic and solar thermal technologies by farmers for the needs of their households as well as for agricultural production.
\end{abstract}

Keywords: photovoltaic installations; solar installations; renewable energy; farmers' households; agricultural holding; agricultural production

\section{Introduction}

In rural areas, investments in renewable energy sources (RESs) can be of great economic, social, and environmental importance (reduction in low-stack gas and dust emissions, reduction in $\mathrm{CO}_{2}$ emissions) [1]. However, this depends mainly on the scale of such investments. RESs have the potential to improve the quality of life of the population and the quality of the environment, and they may constitute an additional source of income or a source of savings for economic entities, local government units, households, and agricultural holdings [2].

Agriculture is one of the sectors that can and should make intensive use of RESs [3-6]. The development of renewable energy sources in agriculture is necessary for several reasons. From the perspective of the sector, this necessity results from the need to reduce the dependence of agriculture on fossil fuels and to achieve specific objectives related to the reduction in $\mathrm{CO}_{2}$ emissions and the so-called low-stack emissions. It is also an opportunity to improve the multifunctionality of agriculture and to use biomass from agricultural production, waste, or roof surfaces.

In Poland, the use of innovative, small-scale renewable energy technologies classified as distributed generation that have given rise to the development of community energy is a relatively new phenomenon but is becoming increasingly important for the development of the renewable energy sector [7]. An example of this may be the significant increase in the use of solar energy initially for water heating and since 2015 also for electricity generation as part of a prosumer system. The growth of this sector is fostered by the increasing 
energy efficiency of installations in relation to their price, as well as by favorable financing conditions in addition to the introduction of favorable legal regulations concerning the prosumer status [8,9]. Thanks to such changes (legal and financing method), the number of investments generating green energy will be increased several times [10]. The report by $R$. Fu et al. [11] also confirms the growing number of the discussed investments. Research conducted by P. Gradziuk is also worth mentioning. In his research, the author lists the decrease in the unit costs of photovoltaic installations, both pro-consumer and commercial, among the factors having a significant impact on the development of PV and solar installations [12]. However, despite such a significant development, the photovoltaic market in Poland, according to many opinions, still has great potential for development [13]. The confirmation is, among others, the results of the research conducted by A. Ciechomska, which indicate still insufficient support for the RES sector [14]. On the other hand, the most frequently implemented investments include photovoltaic and solar panels. It is for their assembly that funds from co-financing are allocated to the greatest extent $[15,16]$.

Solar photovoltaic (PV) and solar thermal systems, i.e., the technology used to convert solar energy into electricity or heat, are gaining increased attention among farmers. For farmers, it is not only an opportunity to reduce household expenses, but above all a chance to reduce the cost of agricultural production. It is also an opportunity to draw agricultural production to a larger extent from ecological solutions [17-19].

Investments in renewable energy sources by rural households and local governments receive support from European Union funds and national budgets [20]. In order to benefit from the financial instruments available to support RES investments, the potential beneficiaries must have certain knowledge and financial competence [21]. Awareness of environmental considerations and appreciation of their importance is also a major factor behind the investment. Therefore, the most important determinants of RES sector development in rural areas in Poland are connected to human resources, as well as to the attitudes of the local population, including farmers, towards RESs. Activities related to the use of renewable energy sources are relatively novel and innovative, and their implementation is associated with business risks.

There is a gap in research on farmers' investment in solar PV and solar thermal installations. In the case of family farms, it is not possible to clearly separate the household from the farm perceived as the workplace of the farmer's family. The household needs are combined with the needs of the agricultural production, which impacts the energy consumption structure [22-25].

The purpose of the study is to identify economic and social factors determining farmers' investments in solar PV and solar thermal installations. The paper also aims to demonstrate what part of the energy produced from RESs is used for the needs of farmers' families and what part is used for agricultural production and then to identify the factors determining this proportion. Achieving these objectives can contribute to a better alignment of policies and tools to support investment in green energy in agriculture.

\section{Factors Determining the Adoption of PV and Solar Installations in the Agriculture}

The adoption of solar PV and solar thermal systems by rural households has been addressed in the literature. Although the studies cover different countries and regions, they most often refer to the following two aspects:

(1) The first aspect that studies often refer to is the reasons why households make the decision to invest in generating energy through PV and solar panel technologies [3]. Labay et al. draw attention to demographic factors in their research [26]. Sidiras and Koukios point to a number of economic, socio-cultural, and political factors [27]. Faiers and Neame show the low importance of environmental features in relation to, inter alia, economic factors [28]. Bollinger et al. indicate, on the other hand, that the appearance of PV and solar installations is increasing among households that already have such installations [29]. On the other hand, Zhai and Williams point out that despite the importance of reducing costs in the case of decisions related to the 
installation of PV panels, with the passage of time, users appreciated the aspect of environmental protection more and more [30]. As the main factor determining the choice of renewable energy investments, Fleiß et al. indicate the economic factor. It is the main determinant of the choice of investments in renewable energy among many others. Factors such as energy autonomy, the belief in environmental protection, or the prestige of having renewable energy investments are still less important than the profitability of investments. [31]. Therefore, the visible trends that determine the choice of this type of installation are still economic factors. Hence, proposals call for a more active policy of disseminating this type of investment and raising awareness of the importance of other factors as equally important [32,33]. The dominance of PV panels among this type of investment is also visible, despite the growing number of other types. PV and solar installations still dominate [34]. The importance of various institutional factors has also been explored in this context. It has been confirmed that RES support policies are important in the rapid diffusion of solar PV and solar thermal technologies. Such policies include in particular provisions for guaranteed tariffs for energy produced in household installations and financial support through grants, subsidies, low-interest loans, and credits. Wustenhagen emphasizes the importance of public policy in promoting renewable energy [35]. Guidolin and Mortarino also emphasize the importance of supporting energy policy [36]. Research by Kwan [37] and Cherrington confirms that without proper support from regulations and subsidies, it will not be possible to efficiently and increasingly popularly invest in RES-type solutions [38]. Jenner et al. emphasize that this policy should be effective and adjusted to the specific needs of potential recipients [39]. In turn, Bauner emphasizes that despite many incentives from the state policy, there is still much room for improvement. The conclusions that he formulates are therefore convergent with the previously cited results speaking of a better and more effective regulatory system [40].

(2) The second aspect that studies often refer to is the features of the households and decision-makers that made solar PV and solar thermal investments [37]. ChodkowskaMiszczuk emphasizes socio-demographic features such as the age of the farm manager, which is one of the most important in this respect. [41]. The socio-demographic characteristics of farms were also the main subject of research by the team led by Brudermann [42]. Similarly, Ba-kundukize et al. have conducted research for Rwanda [43]. In turn, for Indian households, similar studies were carried out by Irfan et al. [44]. In most of the studies cited, the age of the farm manager was found to be of great importance; the approaches taken by local authorities and the qualifications and level of education of farmers were also found to be important factors. In this respect, the attitudes of rural residents towards RES technologies and the possibilities of changing these attitudes towards greater acceptance and implementation have also been studied [45-47].

Relatively few studies have attempted to identify the reasons behind the adoption of solar PV and solar thermal micro-installations by farmers.

The price of conventional electricity is a key stimulus for investment in solar PV and solar thermal micro-installations [48]. This factor is important for all households investing in green energy, but it is critical for farmers because in their case a large amount of energy is consumed by agricultural production in addition to household use. This is especially true for large farms (in terms of farmland area and operating surplus) generating significant energy costs [42].

Previous works show that the adoption of renewable energy in agricultural holdings depends on factors related to the farmer as the farm manager, factors related to the farm, and socio-economic factors [49,50]. As far as the factors related to the farmer are concerned, the propensity to invest in RESs is mainly influenced by the farmer's age and education. Most studies show an inverse relationship between the farmer's age and his/her involvement in RES adoption [49,51-54]. Education, in turn, is a major driver behind investment in renewable technologies [51-54]. The psycho-social characteristics of the person managing 
the farm, such as risk aversion or openness to innovations, are of great importance as well $[49,50]$.

The determinants related to farm characteristics include the size and legal status of the agricultural holding. The probability of undertaking investments in solar PV and solar thermal systems is higher for large area farms [55]. This is due to the increased need for energy and the fact that large agricultural holdings earn relatively more compared to small farms. The legal status of the holding concerns, for example, the ownership or tenancy of the agricultural property. Agricultural property ownership and long-term lease encourage investment in renewable energy production [49].

Farmers' economic interests are an important motivation to invest in RESs [42,56]. Environmental reasons seem to have less influence on farmers' decisions [31,56,57]. However, this may change as a result of environmental education programs, among other things, as pointed out by Shi et al. [58]. It is also worth noting that research most often focuses on farmers' investments in bioenergy production installations exclusively for agricultural production. Investment in solar energy installations is rarely addressed. An additional problem that is often overlooked is that energy generated in such installations is divided into energy for household and farm needs. In such cases, the distribution of farmers' motivation to invest may be different than in the case of investments in biomass or biogas facilities which use media harvested from agricultural production and are used entirely to cover the energy needs of the production process.

Other determinants of farmers' investment in RESs include the farm's agricultural type as defined by its agricultural production structure and the type of economic activity of the farmer $[42,52,54,59,60]$. Using the example of the United States, Borchers et al. [53] showed that organic farms are about five times more likely to adopt renewable energy generation technologies than conventional farms. The type and scale of RES investments in agriculture are also influenced by the biophysical characteristics of the farm such as the amount of sunshine in the area, average wind strength, soil erosion, slope, or precipitation $[49,61]$.

Many studies indicate that household income is the dominant predictor of green energy investments $[37,49,53,54,62,63]$. In the case of agricultural holdings, investments in RESs are more likely if the income from the family farm is high or if there are additional non-farm earnings [51].

Farmers who are well informed about available energy technologies can adopt them faster $[42,49,53,61]$. Brudermann et al. [42] confirm the importance of social and behavioral factors for the adoption of solar PV and solar thermal technologies in agriculture. Such actions are motivated by the desire to strengthen the farmer's position in the local community and by emulation. According to the literature on innovation diffusion, about $3 \%$ of initial adoption is driven by innovators, and later on, adoption is spurred by the imitation effect [64]. However, the scale of investment in solar micro-installations must exceed a certain threshold of prevalence in households for the imitation effect to become clearly visible [47]. Kim and Lee [65] indicate that there is an imitation effect that is part of the local process of learning and applying solar PV and solar thermal technologies.

Research suggests a growing importance of institutional factors closely linked to fiscal and energy policy measures established by individual countries and regions that stimulate the adoption of renewable energy generation systems by agricultural holdings [60]. In the European Union, support for the energy transformation of agriculture towards a sustainable model takes the form of various RES subsidy programs and different support instruments. Poland, for example, has the AgroEnergy (Polish: AgroEnergia) program intended for farmers. It was launched in 2019 and it gives farmers the opportunity to obtain grants from public funds to finance investments in RES micro-installations (with a capacity between 10 and $50 \mathrm{~kW}$ ). The grant may amount to up to $20 \%$ of the project costs, but the subsidized installation should serve to satisfy the beneficiary's own energy needs. Farmer households, just like other households, can also benefit from subsidies for PV installations under the My Electricity (Polish: Mój Prąd-more in the explanations) program or the Clean Air (Polish: Czyste Powietrze-more in the explanations) program and, from 2019, they can 
write off the installation costs from their personal income tax under the so-called thermal modernization relief (after deduction of any subsidies). My Electricity is a program of co-financing photovoltaic micro-installations with an installed capacity of 2 to $10 \mathrm{~kW}$. With the number of applications submitted (actually over 220,000), the total capacity of these installations reaches $1.2 \mathrm{GW}$, with an annual production of approx. $1200 \mathrm{GWh}$ /year [66]. My Electricity program is very popular, especially in the southern regions of Poland. The Podkarpackie region, analyzed in this article, has special, favorable conditions related to insolation. Detailed data also indicate that the Podkarpackie region has a fairly average level of introduced PV power installation [67] while simultaneously having highest average subsidies to power (expressed in $\mathrm{kWp}$ ) [68]. Meanwhile, the Clean Air program strives to improve air quality through the removal of obsolete stoves and boilers and insulation of buildings; so far, it has reached 247,275 entities with support for a total amount of PLN 4.4 billion. Actually, the framework of the next edition of the program has been modified, which should make its implementation more dynamic [69].

In addition, farmers could receive a grant for an RES investment under the EU 20142020 farm modernization support funds. The support will continue under the new EU 2021-2027 financial perspective. Many countries have similar programs to facilitate RES investments in agriculture, but there is still little research investigating their effectiveness in this regard.

The Polish economy needs improvement in terms of energy efficiency and developing a distributed energy system based on renewable sources. Social expectations and Poland's energy obligations resulting from the objectives set by the European Union in its 2030 climate and energy framework [8] are the key drivers for undertakings in this area. They include the following:

- $\quad$ Reducing a minimum of 40\% of greenhouse gas emissions (compared to 1990 levels);

- Increasing the share of energy from renewable sources in the total energy consumption to a minimum of $32 \%$;

- Increasing energy efficiency by a minimum of $32.5 \%[20,70]$.

These targets, although aggregated for the entire EU, impose certain obligations on each member state, which in the case of Poland have been included in the National Energy and Climate Plan for the years 2021-2030. It sets the goal of achieving a 21-23\% share of RESs in gross final energy consumption by 2030 and reducing the share of coal in electricity production to $56-60 \%$ [71].

Poland is still lagging behind the EU average in terms of meeting the targets set in the earlier Directive 2009/28/EC of the European Parliament and of the Council [72] regarding the share of energy from renewable sources in overall energy consumption by 2020 despite the progress in recent years. To be precise, the share of renewable energy in total primary energy generation increased from $12.12 \%$ to $14.31 \%$ (EU average: from $26.1 \%$ to $29.9 \%$ ) between 2014 and 2018. At the same time, the share of renewable energy in gross final energy consumption in 2018 was $11.16 \%$, with a target of $15 \%$ by the end of 2020 [73].

Poland's energy transition and the achievement of the climate and energy targets for 2030 and beyond will not succeed without a widespread development of energy based on renewable energy sources at the local level, including in rural areas and in agriculture.

In Poland, energy consumption differs between rural and urban households. Between 2009 and 2018, the average annual household electricity consumption in rural areas was more than 30\% higher compared to urban areas (Statistics Poland, 2019). This was a direct result of the larger average dwelling size and the larger average number of persons in a household in the rural areas. Additionally, agricultural households consumed on average $24.3 \%$ more electricity for household needs than other households in rural areas [5]. The energy demand of all of the buildings, machinery, and equipment located on the farm usually far exceeds that of regular houses. With regard to solar PV or solar thermal installations, however, this is equivalent to an increase in investment costs due to the required plant capacity. Thus, the economic benefits of an RES installation can be much higher for a farmer than for a non-agricultural household, but the investment costs are 
higher as well. The results of a study by Klepacka et al. [3] indicate that farmers in Poland attach more importance to energy costs as a rationale for RES investments compared to other rural residents.

In Poland, $88.4 \%$ of rural households still use solid fuels, mainly coal and wood, for heating rooms and domestic hot water [73]. The use of fossil fuels causes not only $\mathrm{CO}_{2}$ emissions but also the so-called low-stack emission of many gases and forms of dust that are harmful to health, which is especially true of hard coal combustion. It is estimated that 44,000 people in Poland die prematurely each year as a result of smog caused by low-stack emissions of gases and dust emitted during coal burning in rural and urban household furnaces [74]. Improving air quality is, therefore, a very important part of public health policy.

Increased use of solar energy in rural households reduces their dependence on fossil fuels, lowers the amount of ash discharged to landfills, improves air quality for the local community, and saves money on the monthly household energy bill [5]. There is a need to determine how many other aspects besides economic ones, in particular environmental and health factors, influence farmers' willingness to make investments in green energy. This is particularly important because hard coal and wood are still cheaper than other energy sources.

The issue of reducing the consumption of low-quality fuels and introducing new technologies in agriculture, which serves to reduce air pollution problems and improve the living conditions of farmers, is topical in many countries [75-77]. One solution to this problem is the development of solar PV and solar thermal systems in rural areas and agriculture. In Poland, the rationale behind investments in such systems includes the following:

- Growing demand for electricity on agricultural holdings;

- $\quad$ Reduction in energy consumption from conventional sources, for example as a result of an increase in the price of such energy;

- Reduction in agricultural production costs and in the farmer's family costs associated with the consumption of electricity and heat;

- Increased energy self-reliance and reduced dependence on energy prices;

- $\quad$ Obtaining financial benefits, i.e., grants for the implementation of investments, agricultural tax, and personal income tax reliefs for investment.

\section{Materials and Methods}

The research involved a literature and documentary analysis, as well as analysis of public statistics data. Empirical analyses were based on the results of a diagnostic survey conducted among farmers-owners of family farms in the Podkarpackie region. The research tool was a questionnaire that included questions about RES installations and their use in the respondents' households and farms, factors determining farmers' investment in renewable energy, assessment of the benefits of RESs, and limitations to the development of installations on farms. Targeted selection was used to choose the group of research subjects comprising farmers who had a renewable energy installation or had declared that they would start investing in solar PV or solar thermal installations in 2021. The intention to undertake such an investment was evidenced by the farmer's application for financial support for the investment in a publicly funded program supporting solar PV or solar thermal installations. Respondents were selected from the ODR Boguchwała database (Agricultural Advisory Center in Boguchwała), which keeps a register of the farms in the Podkarpackie region and monitors their functioning and investments. The research was carried out on farms from all 21 poviats of the Podkarpackie region, assumed representativeness for agriculture in the Podkarpackie region, and assumed proportionality in the context of the number of farms in poviats. The minimum sample was set at 226 units and was realized. In case of refusal to participate in the research, another respondent was selected. The study was conducted in Q4 2020. The following research hypotheses were adopted in this study: 
Hypotheses (H1). Factors stimulating the adoption of solar PV and solar thermal installations on farms include the reduction in energy expenses and access to grants for such investments. The young age of the farmer and a larger farm area are also contributing factors.

Hypotheses (H2). On agricultural holdings, a high share of agricultural production in renewable energy consumption reflects farmers' preferences for the economic benefits of RESs.

Hypotheses (H3). Farmer's focus on livestock production and the commercial nature of the farm is a factor that promotes a higher share of agricultural production in the consumption of energy obtained from solar PV and solar thermal installations.

Hypotheses (H4). Younger farmers managing large-scale commercial and specialized farms attach more importance to the reduction in agricultural production costs resulting from the adoption of solar PV and solar thermal installations.

The research hypotheses were verified using logistic regression and multiple regression methods. The chi-squared test $\left(\chi^{2}\right)$ and Cramér's V were also applied.

A logistic regression model was used to verify hypothesis H1. In this model, the dependent variable is dichotomous, i.e., it assumes the value 1 when the desired event occurs or the value 0 when such an event does not occur. For a given case $i$, the probability of the variable y taking the value 1 or 0 is

$$
P\left(y_{i}=1\right)=p_{i}, P\left(y_{i}=0\right)=1-p
$$

The probability is a function of the vector of explanatory variables $x_{i}$ and the parameter vector $\beta$, and therefore,

$$
p_{i}=P\left(y_{i}=1\right)=F\left(x_{i}^{T} \beta\right) ; \text { for } i=1,2, \ldots, n
$$

The logit model assumes that the probability $p_{i}$ corresponds to the distribution of the logistic distribution [78]:

$$
P_{i}=F\left(x_{i}^{T}\right)=\frac{1}{1+\exp \left(-x_{i}^{T} \beta\right)}=\frac{\exp \left(x_{i}^{T} \beta\right)}{1+\exp \left(x_{i}^{T} \beta\right)}
$$

The parameters (coefficients) of the logistic regression model are estimated using the maximum likelihood method [79]. Parameters $\beta_{0}, \beta_{1}, \ldots, \beta_{k}$ for known values $y_{i}, x_{1 i}, \ldots$, $x_{k i}$ must be estimated in such a way that they provide the maximum value of the logarithm of the reliability function.

The logistic regression model can be defined in more detail:

$$
P\left(Y=1 \mid x_{i}, \ldots, x_{k}\right)=\frac{\exp ^{\beta_{0}+\beta_{1} x_{1}+\ldots+\beta_{k} x_{k}}}{1+\exp ^{\beta_{0}+\beta_{1} x_{1}+\ldots+\beta_{k} x_{k}}}
$$

where $\beta_{1}, \ldots, \beta_{\mathrm{k}}$ are logistic regression coefficients.

In the analysis under consideration, the fact that the household owns/does not own a solar PV and/or solar thermal installation was interpreted as an explanatory variable (denoted by $Y_{1}$ ). The variable $Y_{1}$ was defined as follows:

$$
Y_{1 i}=\left\{\begin{array}{c}
1 \text { if the } i_{\text {th }} \text { household has a solar PV and / or solar thermal energy system } \\
0 \text { if the } i_{\text {th }} \text { household does not have such an installation }
\end{array}\right.
$$

where $i=1,2, \ldots, n$ and is the number of surveyed households.

The dependent variable $\left(Y_{1}\right)$ was determined for all 226 studied units. The input set of independent variables for the estimation of the logistic regression model consisted of variables marked with symbols from $X_{1}$ to $X_{10}$ (Table 1). The selection of explanatory variables was based on a correlation matrix, and the selected variables were significantly associated with the dependent variable $Y_{1}$. 
Table 1. Explanatory variables used for the estimation of logistic and multiple regression models.

\begin{tabular}{|c|c|c|c|}
\hline \multirow[b]{2}{*}{ Variable } & \multirow[b]{2}{*}{ Symbol } & \multicolumn{2}{|c|}{ Regression } \\
\hline & & $\begin{array}{c}\text { Logit } \\
\mathrm{Y}_{1 i}\end{array}$ & $\begin{array}{c}\text { Multiple } \\
\mathrm{Y}_{2 i}\end{array}$ \\
\hline Having other RES installations $(0 / 1)$ & $\mathrm{X}_{1}$ & + & + \\
\hline Age of the farm manager (years) & $X_{2}$ & + & + \\
\hline Farm area (ha of agricultural land) & $x_{3}$ & + & + \\
\hline $\begin{array}{l}\text { Using repayable funds (loans, leasing) to finance investments in } \\
\text { renewable energy }(0 / 1)\end{array}$ & $\mathrm{X}_{4}$ & + & + \\
\hline Use of renewable energy subsidies $(0 / 1)$ & $\mathrm{X}_{5}$ & + & + \\
\hline Specialized or targeted holding $(0 / 1)$ & $X_{6}$ & + & + \\
\hline Saving energy costs is of great importance (points 1-3) & $x_{7}$ & + & + \\
\hline Environmental responsibility is of great importance $(0 / 1)$ & $\mathrm{X}_{8}$ & + & + \\
\hline It is of great importance to increase the quality of life $(0 / 1)$ & $X_{9}$ & + & + \\
\hline Neighborly prestige is of great importance $(0 / 1)$ & $X_{10}$ & + & + \\
\hline High importance of tax benefits (pkt 1-2) & $\mathrm{X}_{11}$ & - & + \\
\hline Use of undeveloped space $(0 / 1)$ & $\mathrm{X}_{12}$ & - & + \\
\hline The farm is focused on animal production $(0 / 1)$ & $\mathrm{X}_{13}$ & - & + \\
\hline The farm functions as a special department $(0 / 1)$ & $\mathrm{X}_{14}$ & - & + \\
\hline The farm carries out organic production $(0 / 1)$ & $\mathrm{X}_{15}$ & - & + \\
\hline The farm runs agritourism production $(0 / 1)$ & $\mathrm{X}_{16}$ & - & + \\
\hline The farm sells agricultural products $(0 / 1)$ & $X_{17}$ & - & + \\
\hline A farm associated in a production group $(0 / 1)$ & $\mathrm{X}_{18}$ & - & + \\
\hline VAT on general terms $(0 / 1)$ & $\mathrm{X}_{19}$ & - & + \\
\hline
\end{tabular}

"+" use of a variable for modeling, "-" variable omission. Source: own survey.

Analysis involving the multiple regression method was used to verify hypotheses $\mathrm{H} 2$ and H3. $Y_{2 i}$ is the share of energy obtained from RESs used for agricultural production (in \%) and was adopted as the dependent variable. The multiple linear regression model looks as follows [80]:

$$
Y_{2 i}=\beta_{0}+\beta_{1 \times 1}+\beta_{2} X_{2}+\ldots+\beta_{k} X_{k}+\varepsilon t
$$

where $Y_{2 i}$ is the dependent variable explained by the model; $X_{1}, X_{2}, \ldots, X_{k}$ are independent (explanatory) variables; $\mathrm{B}_{0}, \beta_{1}, \beta_{2}, \ldots, \beta_{k}$ are parameters; and $\varepsilon_{t}$ is a random (residual) component.

The coefficients for the model are estimated using the classic ordinary least squares (OLS) method. Based on these values, the direction and strength of the influence of the independent variables on the dependent variable can be inferred. Student's $t$-test was used to determine the statistical significance of individual regression coefficients for independent variables. The quality of the multiple regression model was assessed using an $\mathrm{F}$ test, the variance of the random component $(\varepsilon t)$, a normality test of the residual component, and the coefficient of determination $R^{2}$.

The estimation of the multiple regression model was preceded by a collinearity analysis of the variables, which removed relatively highly correlated preselected explanatory variables from the analysis (Pearson's correlation coefficient $\left.r_{x y}>0.7\right)$. Backward stepwise regression was used in the estimation of the regression model.

The dependent variable $\left(Y_{2}\right)$ was determined for 150 units, i.e., those that had solar $\mathrm{PV}$ and solar thermal installations. Variables marked with symbols from $X_{1}$ to $X_{19}$ were initially qualified for the analysis (Table 1). The estimation of the regression model was preceded by an analysis of the interdependence of the independent variables, as a result of which the variables $X_{4}$ and $X_{19}$ were eliminated.

The chi-squared test of independence $\left(\chi^{2}\right)$ and Cramér's V coefficient were used to verify hypothesis H4. The independence test allowed us to verify the hypothesis of the independence of the two variables $X_{i}$ and $Y_{i}$ measured on nominal scales [81]: $\mathrm{H} 0$, features $X_{i}$ and $Y_{i}$ are independent; $\mathrm{H} 1$, features $X_{i}$ and $Y_{i}$ are dependent, with an assumed significance level of $\alpha=0.05$. In this analysis, the benefits from an RES installation were shown as $X_{i}$ features ( 8 variables were selected), while 5 features describing the farmer and the farm were shown as Yi features. 
To verify the hypotheses, a $\chi^{2}$ statistic, expressed as the following formula, was used:

$$
\chi^{2}=\sum_{i=1}^{r} \sum_{j=1}^{k} \frac{\left(n_{i j}-\hat{n}_{i j}\right)^{2}}{\hat{n}_{i j}}
$$

In order to determine the strength of the relationship between the studied features, Cramér's V coefficient was used, which was calculated as follows [82]:

$$
V_{C}=\sqrt{\frac{\chi^{2}}{N \cdot(\min (k, r)-1)}}
$$

where $V_{c}$ is Cramér's V coefficient, $\chi^{2}$ is chi-squared, $k$ is the number of rows, and $r$ is the number of columns in the correlation table.

Cramér's $V$ coefficient assumes values [0,1], where $V=0$ indicates independence of features and $V=1$ indicates a strong relationship.

\section{Results of Empirical Studies}

\subsection{PV and Solar Installations at Farmers' Households in the Podkarpackie Region}

The research carried out in the Podkarpackie region on a purposefully selected sample of 226 farms indicates that $66.4 \%$ of the units had an installation for generating energy from renewable sources and $73 \%$ intended to invest in this type of installation in the future (Figure 1). As the criterion for the inclusion of households in the sample was the ownership of a solar PV/solar thermal installation or the intention to implement such an installation within the following year, these results may not come as a surprise. Two-thirds of the surveyed farmers had already made such an investment, while the remaining group (33.6\%) intended to do so. At the same time, as many as $39.4 \%$ of the farmers who already had an RES installation (e.g., solar thermal) intended to invest in another installation (e.g., a solar PV installation).

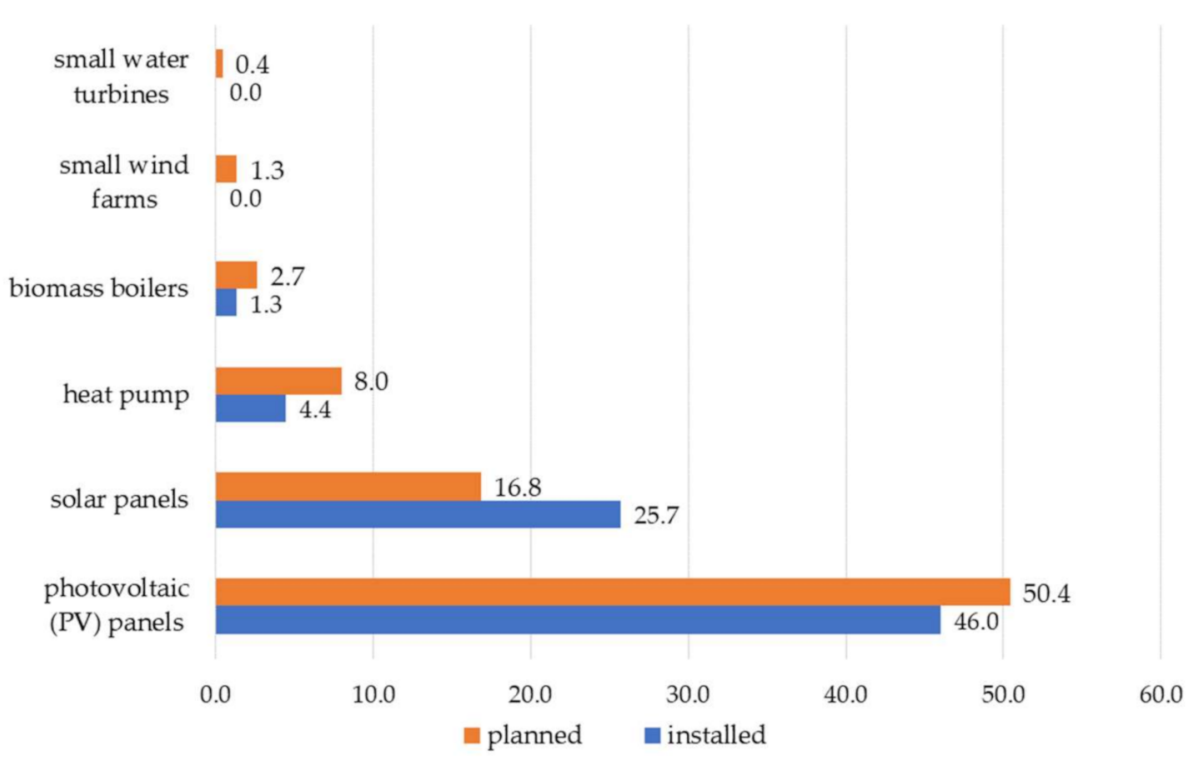

Figure 1. Percentage of researched farms owning and planning RES installations (\%). Source: own survey.

The research was not carried out on a random sample; hence, it was not possible to determine what percentage of farms in the region have an RES installation, but the high dynamics of change that took place between 2015 and 2020 in this area are clearly visible. Research conducted in the Podkarpackie region in 2014 [83] showed that the vast majority of residents of municipalities with a dominant agricultural profile did not use 
renewable energy sources. The respondents showed potential interest in solar collectors and photovoltaic systems; however, most of them stated that they could not afford such investments due to the investment costs in relation to the respondents' income and the long period of return on investment. The dynamic technical progress that took place between 2015 and 2020, especially in the segment of solar PV installations, the emergence of financial support programs for this type of investment, the personal income tax reliefs from 2019, and finally the improvement of farmers' income [84] have made PV technology much more accessible to farmers, and the number of such installations has increased significantly. In Poland, particularly dynamic growth took place in the prosumer PV micro-installation segment between 2018 and 2020. By 2020, electricity was generated in 458,600 PV microinstallations, and their total capacity was over $3000 \mathrm{MW}$. In comparison, at the end of 2019, there were 155,100 such installations; at the end of 2018, there were only 51,000, and the capacity of the micro-installations was $344 \mathrm{MW}$ [85]. There are no detailed data on how many of these micro-installations are located in rural areas and how many of them are found in agricultural holdings. It can be estimated that about three-quarters of prosumer PV installations are located in rural areas, and of these at least $30 \%$ can be found in farmers' households. This means that between 2018 and 2020, the number of PV installations in farmers' households increased from about 11,500 to 103,000 nationwide. A similar growth dynamic was also observed in the Podkarpackie region.

The surveyed farms had mainly photovoltaic installations ( $46.0 \%$ of farms in total), solar collectors $(25.7 \%)$, heat pumps $(4.4 \%)$, and biomass boilers $(1.3 \%)$. PV installations also prevail in the case of RES investments planned to be implemented. Over $50 \%$ of farm-ers declared making such an investment within a year. Solar collectors are planned to be installed by almost $26 \%$ of respondents, heat pumps by $8 \%$, and biomass boilers by $2.7 \%$. Very few farmers planned to adapt a small wind power plant or a small water turbine, while no respondent declared investment in a micro gas plant.

The structure of farms in terms of the use of energy generated from eco-energy installations is presented in Table 2.

Table 2. The direction of using energy from renewable sources in the researched farms (\%).

\begin{tabular}{cccc}
\hline \multirow{2}{*}{ No. } & Direction of Using Energy from RES & \multicolumn{2}{c}{ Percentage of Farms } \\
\cline { 3 - 4 } & & With a Photovoltaic Installation & With Solar Installation \\
\hline 1 & Only in the household & 41.4 & 84.5 \\
2 & Only for agricultural production & 6.3 & 8.6 \\
3 & Both in agricultural production and in & 52.3 & 6.9 \\
\hline
\end{tabular}

Source: own survey.

Among the agricultural holdings equipped with PV systems, almost $42 \%$ use the electricity generated by the systems only for their household needs (Table 2). Photovoltaic panels were usually placed on residential buildings on these farms, and the farmers were prosumers. On the other hand, $6.3 \%$ of respondents used energy only for broadly defined agricultural production (including drying, cooling, and storage of agricultural products, as well as packaging and preparing products for sale). In this case, PV panels were usually placed on buildings and outbuildings (e.g., warehouses, storage facilities). The largest group of households with PV installations (52.3\%) used the obtained energy both for household purposes and for agricultural production. In the case of units with a solar thermal installation, the vast majority $(84.5 \%)$ used the acquired thermal energy only in the household. Only $8.6 \%$ of the farmers used the solar thermal installation for agricultural production, while $6.9 \%$ divided the acquired energy into consumption related to agricultural production and consumption related to the family's household needs.

The highest percentage of units with solar PV installations was found among mixedproduction farms and farms focused on livestock production (over $60 \%$ ). These groups of holdings, as well as holdings operating as so-called special branches of agricultural 
production (e.g., crops grown in greenhouses and foil tunnels, poultry farms) also included the largest number of units equipped with solar thermal installations (Table 3). The smallest number of solar PV and solar thermal installations was declared by holdings that perform agricultural activities related only to the maintenance of agricultural land in good agricultural condition (Table 3).

Table 3. The use of energy from renewable sources in the researched farms, taking into account the type of farm (\%).

\begin{tabular}{|c|c|c|c|c|c|c|c|c|c|c|}
\hline \multirow{3}{*}{ No. } & \multirow{3}{*}{ Farm Profile } & \multirow{2}{*}{\multicolumn{3}{|c|}{$\begin{array}{l}\text { Percentage of Farms in the Group } \\
\text { with an Installation }\end{array}$}} & \multicolumn{6}{|c|}{$\begin{array}{l}\text { Share of Farms in the Group by Area of Energy Use } \\
\text { for the Purposes of: }\end{array}$} \\
\hline & & & & & \multicolumn{3}{|c|}{$\begin{array}{l}\text { Only Agricultural } \\
\text { Production }\end{array}$} & \multicolumn{3}{|c|}{$\begin{array}{c}\text { Agricultural and Living Production } \\
\text { of the Family }\end{array}$} \\
\hline & & PV & Solar & Other RES & PV & Solar & Other RES & PV & Solar & Other RES \\
\hline 1. & $\begin{array}{l}\text { Plant production } \\
\text { oriented }^{1}\end{array}$ & 48.6 & 33.8 & 8.3 & 2.9 & - & - & 62.9 & 22.6 & 33.3 \\
\hline 2. & $\begin{array}{l}\text { Animal production } \\
\text { oriented }^{2}\end{array}$ & 60.7 & 43.1 & 14.3 & 5.9 & 28.6 & - & 70.6 & 28.6 & 25.0 \\
\hline 3. & Special department ${ }^{3}$ & 50.0 & 50.0 & - & - & - & - & 100.0 & 100.0 & - \\
\hline 4. & $\begin{array}{l}\text { Multidirectional farms } \\
\text { Only those keeping the }\end{array}$ & 62.2 & 47.6 & 4.0 & 6.5 & 4.0 & - & 47.8 & 40.0 & - \\
\hline 5. & $\begin{array}{l}\text { land in good agricultural } \\
\text { condition } 5\end{array}$ & 47.6 & 25.0 & 4.8 & 10.0 & 10.0 & - & 20.0 & 10.0 & - \\
\hline 6. & Ecological ${ }^{6}$ & 50.0 & 25.0 & 25.0 & 50.0 & 100.0 & - & - & - & - \\
\hline 7. & $\begin{array}{l}\text { Conducting agritourism } \\
\text { activities } 7\end{array}$ & 50.0 & - & 50.0 & - & - & - & - & - & - \\
\hline
\end{tabular}

Number of respondents: ${ }^{1} 72,{ }^{2} 28,{ }^{3} 4,{ }^{4} 74,{ }^{5} 21,{ }^{6} 4,{ }^{7} 2$. Source: own survey.

In terms of agricultural production purposes, energy from solar PV installations is used for lighting farm premises, powering machinery and equipment on the farm, and heating water, as well as cooling or drying products, while energy from solar thermal installations is mainly used for heating water (Table 4).

Table 4. Ways of using energy from renewable sources in the researched farms.

\begin{tabular}{|c|c|c|c|c|}
\hline \multirow{2}{*}{ No. } & \multirow{2}{*}{$\begin{array}{l}\text { Objectives of the Use } \\
\text { of Renewable Energy }\end{array}$} & \multicolumn{3}{|c|}{ Type of RES Installation } \\
\hline & & Photovoltaic & Solar & Other \\
\hline & \multicolumn{4}{|c|}{ Household } \\
\hline 1 & Lighting of living quarters & 3.8 & - & 0.5 \\
\hline 2 & Domestic water heating & 2.5 & 3.0 & 1.5 \\
\hline 3 & Heating of living quarters & 1.8 & 0.7 & 1.7 \\
\hline 4 & Air conditioning, ventilation & 0.7 & - & 0.2 \\
\hline \multirow[t]{2}{*}{5} & Other & 0.1 & - & - \\
\hline & \multicolumn{4}{|c|}{ Agricultural Production } \\
\hline 1 & Room lighting & 2.5 & - & 0.2 \\
\hline 2 & Heating water for agricultural production & 1.3 & 2.0 & 0.4 \\
\hline 3 & Product cooling & 1.0 & - & 0.1 \\
\hline 4 & Drying of agricultural produce & 0.8 & - & 0.1 \\
\hline 5 & Space heating or cooling & 0.6 & 0.5 & 0.5 \\
\hline 6 & Drive of agricultural vehicles and machines & 0.5 & - & - \\
\hline 7 & Irrigation or drainage of land & 0.3 & - & 0.1 \\
\hline 8 & Other & 0.2 & - & - \\
\hline
\end{tabular}

Use on a scale of $0-5$, where 0 -none, 1 -small scale, 2-medium scale, 3-large scale, 5-very large use. Source: own survey.

Respondents' statements indicate that the most important determinant of investment in various types of RESs was the desire to reduce household maintenance costs (mean score of 4.6 on a 5-point scale). The availability of grants and other low-cost sources of funding and the reduction in the environmental burden of agricultural production were identified as factors of high importance. On the other hand, respondents attributed moderate importance to such benefits as reduction in agricultural production costs, popularity of RESs, and increase in farm income (Figure 2). The wish to utilize residues (waste, by-products) from 
agricultural production was not an important reason for farmers to invest in RESs. This last observation points to a major challenge in the context of a wider inclusion of agriculture in Poland in the implementation of the concept of a circular economy [86]. It should also be noted that the primacy of household benefits over farm benefits as a determinant of farmers' RES investments may be due to two reasons:

(1) Low importance of farm income in the disposable income structure of many farming families, which particularly applies to small farms that dominate in the studied region (the average area of farmland in 2020 here was only 4.9 ha, compared to the national average of 11 ha) [87];

(2) Underestimation by some farmers of the potential benefits of green energy for agricultural production.

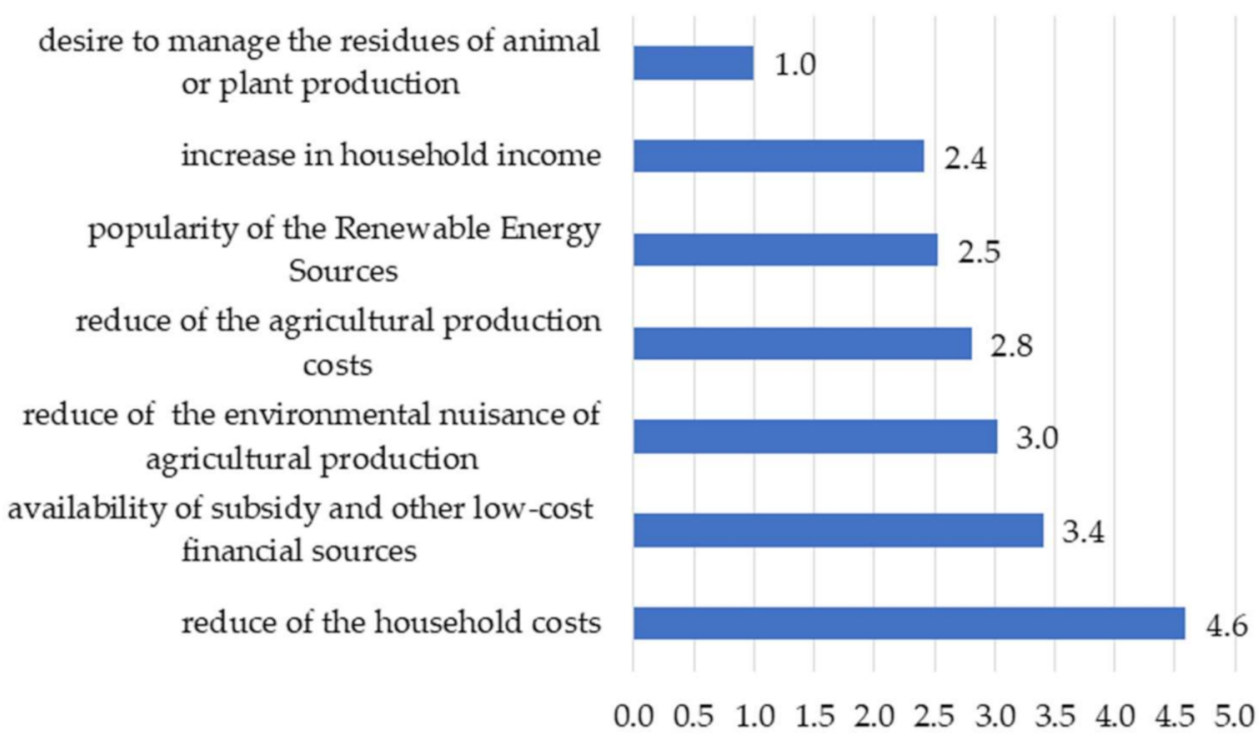

Figure 2. The importance of factors determining investments in renewable energy in the opinion of the surveyed farmers (rating scale from 0 to 5, where 0 -not important and 5-very important). Source: own survey.

The most important barrier that hindered or discouraged farmers from investing in RESs was the low profitability of the investment resulting from the long payback period (mean score of 3.1 on a 5-point scale). The farmers also indicated the high costs of loans, the necessity to obtain numerous documents, technical problems with RES installation and operation, a lack of time to deal with new tasks, and a lack of knowledge on RESs. The farmers attributed moderate importance to these barriers, while other constraints identified by them were rated as insignificant (Figure 3). Looking at the average ratings of determinants and barriers to RES investment, it can be seen that barriers were assigned lower weights. According to the farmers, it was worthwhile to undertake such projects despite the difficulties and constraints.

The farmers financed investments in RESs mainly from their own funds and grants (Table 5). In their financing structure, own funds accounted for $59 \%$ on average, but in the case of $73.4 \%$ of the surveyed holdings, own funds covered at least three-fourths of the amount of investment expenditure. On the other hand, grants and tax reliefs accounted for $34.4 \%$ on average in the structure of investment expenditures. The share of bank credits and loans was very low $(5.9 \%)$, and leasing was completely marginal. The financing structure of the planned investments looked slightly different (Table 5). The farmers expected that about half of the investment costs would be covered from grants and tax relief, which were planned to be used by as many as $88.1 \%$ of respondents. The farmers were also slightly more willing to finance such ventures through loans and leasing, which were chosen by $21.7 \%$ of prospective investors (Table 5). In general, however, the farmers conditioned the 
implementation of investments in photovoltaic and solar installations on access to financial support from public funds.

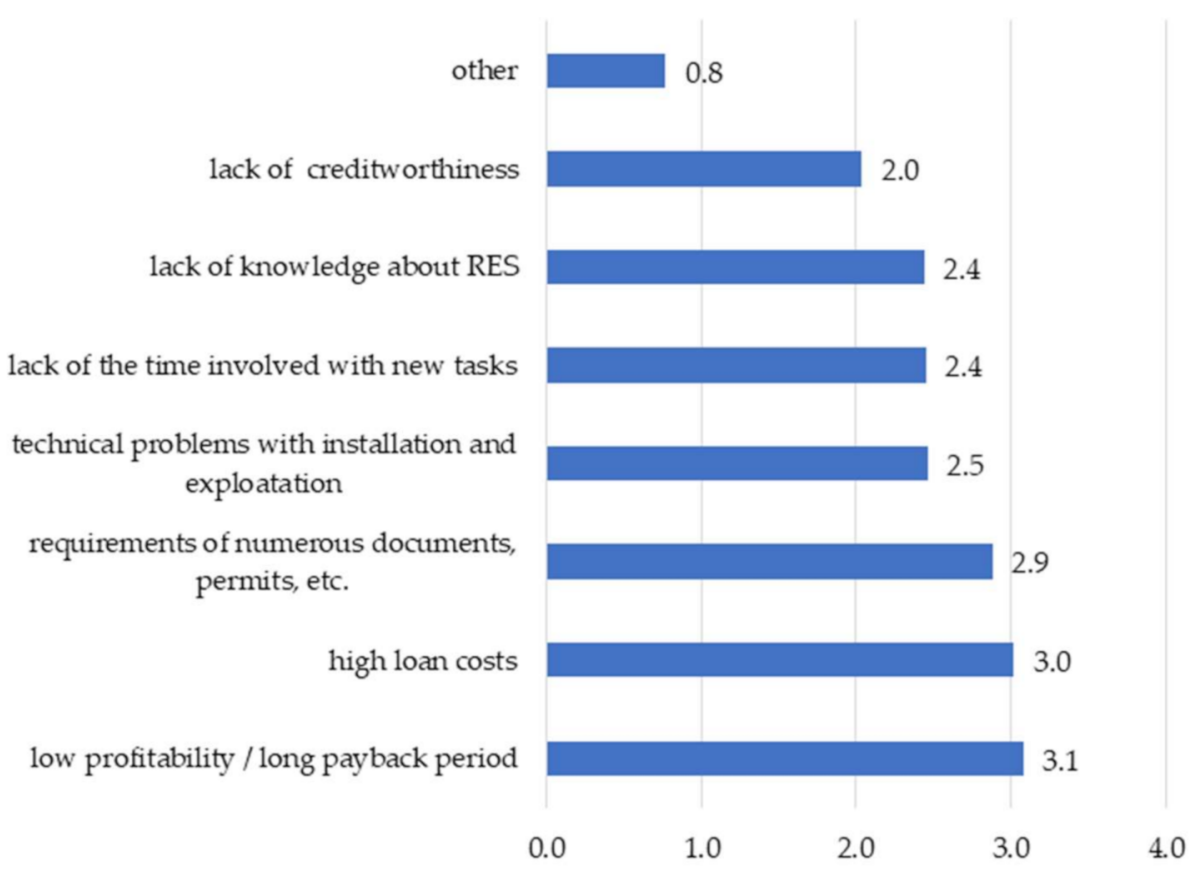

Figure 3. Barriers limiting farmers' interest in investing in PV and solar installations (rating scale from 0 to 5, where 0-not important and 5-very important). Source: own survey.

Table 5. Sources of financing for RES installations in the researched farms.

\begin{tabular}{cccccc}
\hline & & $\begin{array}{c}\text { Type of } \\
\text { Funding } \\
\text { No. }\end{array}$ & $\begin{array}{c}\text { Structure of Financing } \\
\text { Investments in Renewable } \\
\text { Energy (\%) }\end{array}$ & $\begin{array}{c}\text { Percentage of Farmers Engaging } \\
\text { Specific Sources of Financing } \\
\mathbf{( \% )}\end{array}$ \\
\cline { 3 - 6 } & Implemented & Planned & $\begin{array}{c}\text { Completed } \\
\text { Investments }\end{array}$ & $\begin{array}{c}\text { Planned } \\
\text { Investments }\end{array}$ \\
\hline 1 & $\begin{array}{c}\text { Own funds } \\
\text { Bank credit, } \\
\text { loans }\end{array}$ & 59.0 & 42.8 & 87.3 & 88.8 \\
\hline 3 & $\begin{array}{c}\text { Subsidies, tax } \\
\text { breaks } \\
\text { Leasing }\end{array}$ & 3.9 & 7.5 & 12.0 & 18.2 \\
4 & 0.7 & 1.9 & 69.3 & 88.1 \\
\hline
\end{tabular}

Source: own survey research.

The assessment of the benefits of solar PV or solar thermal systems is largely a reflection of the factors determining investment in such technologies. Respondents ranked saving expenses on electricity consumption as the most important benefit, as well as hedging against conventional energy price increases and the associated increase in energy independence of the household (Figure 4). Respondents also gave high priority to environmental aspects. This indicates high environmental awareness of farmers who had invested or intended to invest in RES installations. Increased quality of life through the use of green energy technologies was also of great importance for the respondents, which can also be associated with environmental benefits. 


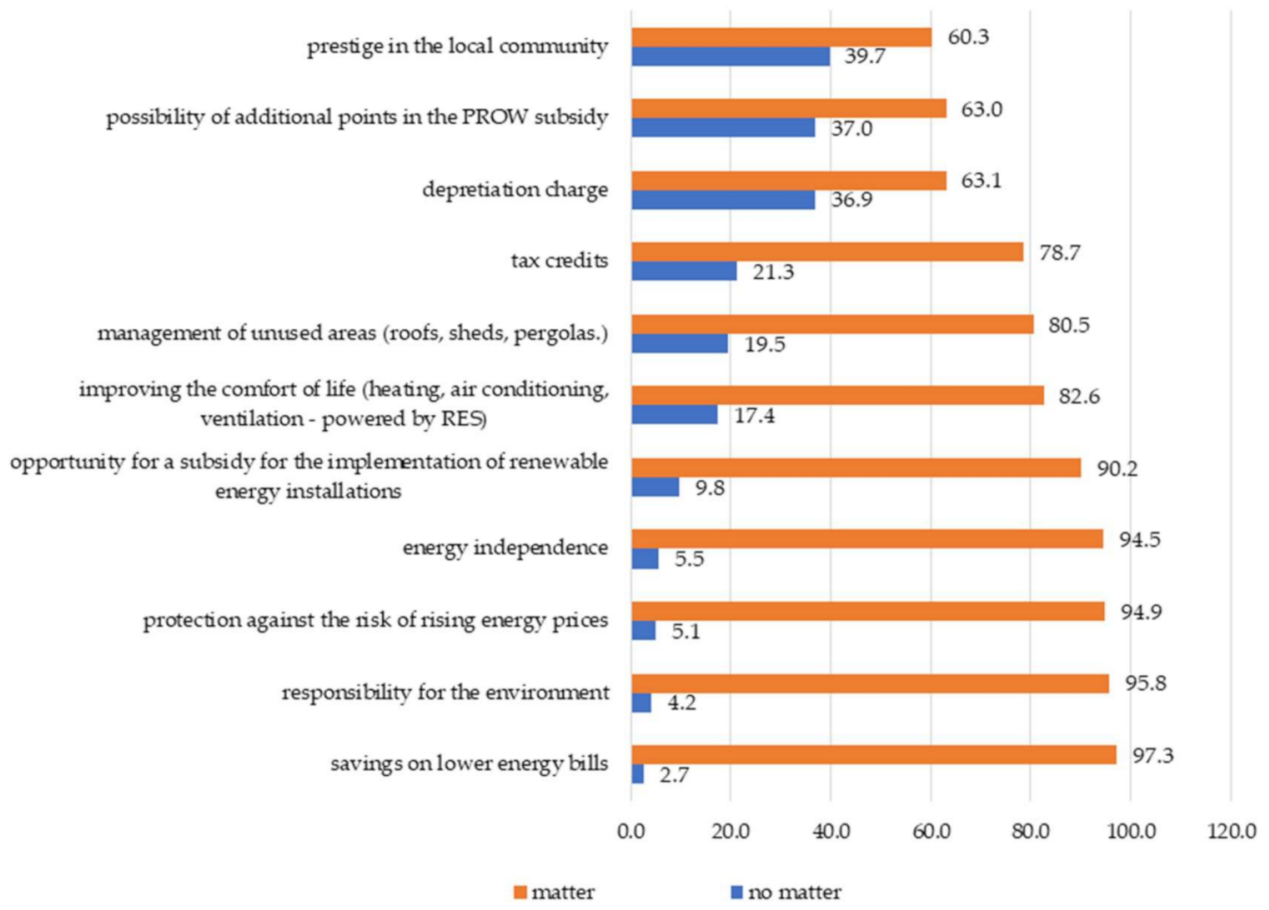

Figure 4. Assessment of benefits resulting from PV and solar installations in farmers' households (\%). Source: own survey.

In addition to the above-mentioned economic benefits, the farmers also pointed to the possibility of obtaining grants for solar PV and solar thermal installations, thus reducing their own investment outlays. Slightly fewer farmers recognized the importance of tax benefits (personal income and agricultural tax reliefs, depreciation write-offs) or indicated the prestige in the local community associated with the ownership of RES installations.

\subsection{Statistical Analysis}

The results of the estimation of the logistic regression model establishing the determinants of farmers' investment in solar PV and solar thermal installations are presented in Table 6. The significance of the statistical parameters of the model was verified based on Student's $t$-test, and the adopted level of significance was $\alpha=0.05$. The model parameters for the variables $X_{1}, X_{2}, X_{3}$, and $X_{5}$ were found to be statistically significant, so the factors mentioned above have a significant effect on the probability of owning PV panels or solar thermal installations. A positive parameter estimate for the variable $X_{1}$ means that the household's ownership of an RES installation positively influences the probability of getting another solar PV or solar thermal installation. Another statistically significant variable is the age of the farmer acting as the farm manager. In this case, the older the farmer, the less likely he/she is to have a first or subsequent RES installation on the farm. The area of a farm and farmer's eligibility for RES grants were also indicated as important determinants of investment in solar PV or solar thermal installations.

The estimated logistic regression model enables, to a large extent, the adoption of hypothesis H1, which assumes that the young age of the farmer, a larger farm area, and the possibility to benefit from RES grants will stimulate farmers' investments in solar PV and solar thermal systems. At this stage of the research, only the high importance of energy expenditure savings as a stimulant for such investments was not confirmed. 
Table 6. Parameters of the logit regression model for the $Y_{1}$ variable determining the probability of having a PV or solar installation.

\begin{tabular}{lcccc}
\hline \multicolumn{1}{c}{ Variable } & Factor & $\begin{array}{c}\text { Standard } \\
\text { Error }\end{array}$ & $t$-Statistic & $p$-Value \\
\hline $\begin{array}{l}\text { Const } \\
X_{1} \text {-Having other RES }\end{array}$ & 3.82243 & 1.5108 & 2.5300 & 0.0391 \\
$\begin{array}{l}\text { installations (0/1) } \\
\begin{array}{l}X_{2} \text {-Farmer's age } \\
\text { years) }\end{array}\end{array}$ & 2.91298 & 0.7041 & 4.1370 & 0.0434 \\
$\begin{array}{l}X_{3} \text {-Farm area (ha of } \\
\text { agricultural land) }\end{array}$ & -2.29318 & 1.1629 & -1.9720 & 0.0172 \\
$\begin{array}{l}X_{5} \text {-Use of renewable } \\
\text { energy subsidies }(0 / 1)\end{array}$ & 1.965383 & 0.4779 & 2.0001 & 0.0161 \\
\hline
\end{tabular}

Number of observations 226, $p$-value $=0.05$

Number of cases of correct prediction $91.6 \%$ Chi-square 93.27, Corrected $\mathrm{R}^{2} 0.37$, McFadden $\mathrm{R}^{2} 0.55$

Source: own survey.

The multiple regression method was used to analyze the determinants of the share of agricultural production in the RES energy consumption structure. The estimated regression model included five independent variables that showed a statistically significant effect on the dependent variable (at $p<0.05$ ). The regression equation explains the studied phenomenon relatively well, as evidenced by the coefficient $\mathrm{R}^{2}$ of $77.4 \%$ (Table 7 ). White's test indicates that heteroscedasticity does not occur, which proves the statistical significance of the regression model. Similarly, the distribution of the residuals of the model has the characteristics of a normal distribution (Table 7).

Table 7. Parameters of the multiple regression model for the $Y_{2}$ variable describing the share of energy obtained from PV and solar installations used for agricultural production.

\begin{tabular}{lcccc}
\hline \multicolumn{1}{c}{ Variable } & Factor & $\begin{array}{c}\text { Standard } \\
\text { Error }\end{array}$ & $t$-Statistic & $p$-Value \\
\hline $\begin{array}{l}\text { Const } \\
X_{2} \text {-Farmer's age } \\
\text { (years) }\end{array}$ & 1.7389 & 2.1971 & 0.7915 & 0.0041 \\
$\begin{array}{l}X_{3} \text {-Farm area (ha of } \\
\text { agricultural land) }\end{array}$ & -2.1109 & 0.2378 & -8.8768 & 0.0178 \\
$X_{7}$-Saving energy & 1.2119 & 0.1781 & 6.8046 & 0.0206 \\
$\begin{array}{l}\text { costs is of great } \\
\text { importance }\end{array}$ & 1.7927 & 2.4493 & 0.7319 & 0.0083 \\
$\begin{array}{l}X_{13} \text { The farm is } \\
\text { focused on animal } \\
\text { production }\end{array}$ & 0.3762 & 6.7281 & 0.0560 & \\
$X_{17}$-The farm sells & & & 0.0439 \\
agricultural products & 0.9781 & 0.8291 & 1.1797 & 0.0349 \\
\hline
\end{tabular}

Number of observations 150, $p$-value $=0.05$, F 0.0076

$\mathrm{R} 0.879, \mathrm{R}^{2} 0.774$, Corrected $\mathrm{R}^{2} 0.683$

AIC 143.479, White's test 0.454 , Test for the normality of the distribution of residuals 0.0799

Source: own survey.

The regression model shows that the age of the farm manager has a significant impact on the share of energy obtained from RESs used for agricultural production. The relationship is inverse, which means that as the farmer's age increases, the share of green energy used for agricultural production in the energy consumption structure decreases. A positive effect on the explained variable was shown for farm area $\left(X_{3}\right)$. The high importance of savings in energy expenditure as perceived by the farmer is associated with greater use of RES energy for farm purposes, which allows us to accept hypothesis H2. A similar 
relationship concerns farm features such as commercial nature and focus on livestock production, which in turn allows us to accept hypothesis H3.

The $\chi^{2}$ test of independence was used to determine the relationship between the farmer and farm features and the farmers' declared benefits of implementing solar PV and solar thermal installations. When the null hypothesis $\mathrm{HO}$ indicating independence of features was rejected in favor of the alternative hypothesis $\mathrm{H1}$, the strength of the relationship between the features was assessed using Cramér's V coefficient. The results of the conducted testing are shown in Table 8.

Table 8. The results of the $\chi^{2}$ and V-Cramer (VC) tests describing the relationships between the characteristics of farmers and their farms and the benefits of PV and solar installations.

\begin{tabular}{|c|c|c|c|c|c|}
\hline $\begin{array}{c}\text { Benefits of } \\
\text { RES } \\
\text { Installations }\end{array}$ & Holding Area & Farmer's Age & $\begin{array}{c}\text { Farm } \\
\text { Commodity }\end{array}$ & $\begin{array}{c}\text { Direction of } \\
\text { Agricultural } \\
\text { Production }\end{array}$ & $\begin{array}{l}\text { Form of } \\
\text { Taxation }\end{array}$ \\
\hline $\begin{array}{l}\text { Environmental } \\
\text { benefits }\end{array}$ & 0.32260 & 0.40162 & $\begin{array}{c}0.03642 \\
\mathrm{VC}=0.244\end{array}$ & $\begin{array}{c}0.00898 \\
\mathrm{VC}=0.250\end{array}$ & 0.29074 \\
\hline $\begin{array}{l}\text { Reducing } \\
\text { household } \\
\text { expenses }\end{array}$ & 0.07938 & 0.87685 & 0.74990 & 0.80779 & 0.39668 \\
\hline $\begin{array}{l}\text { Reduction in } \\
\text { agricultural } \\
\text { production } \\
\text { costs }\end{array}$ & $\begin{array}{c}0.02028 \\
\mathrm{VC}=0.258\end{array}$ & 0.12588 & $\begin{array}{c}0.00500 \\
\mathrm{VC}=0.287\end{array}$ & $\begin{array}{c}0.04700 \\
\mathrm{VC}=0.230\end{array}$ & 0.25008 \\
\hline Tax benefits & 0.15375 & 0.73025 & $\begin{array}{c}0.013474 \\
\mathrm{VC}=0.210\end{array}$ & 0.46465 & $\begin{array}{c}0.047089 \\
\mathrm{VC}=0.157\end{array}$ \\
\hline $\begin{array}{l}\text { The possibility } \\
\text { of selling } \\
\text { surplus energy }\end{array}$ & 0.67912 & 0.24905 & $\begin{array}{c}0.03024 \\
\mathrm{VC}=0.257\end{array}$ & 0.37347 & 0.66543 \\
\hline $\begin{array}{l}\text { Availability of } \\
\text { grants and } \\
\text { other low-cost } \\
\text { sources of } \\
\text { funding }\end{array}$ & $\begin{array}{c}0.04533 \\
\mathrm{VC}=0.229\end{array}$ & 0.12665 & $\begin{array}{c}0.00410 \\
\mathrm{VC}=0.297\end{array}$ & 0.20131 & $\begin{array}{c}0.029346 \\
\mathrm{VC}=0.185\end{array}$ \\
\hline $\begin{array}{l}\text { Prestige, } \\
\text { recognition in } \\
\text { the local } \\
\text { community }\end{array}$ & 0.31922 & 0.65037 & $\begin{array}{c}0.04219 \\
\mathrm{VC}=0.237\end{array}$ & 0.24749 & 0.28013 \\
\hline $\begin{array}{l}\text { Increasing the } \\
\text { quality of life }\end{array}$ & 0.12832 & 0.56699 & 0.1245 & 0.2232 & $\begin{array}{c}0.02402 \\
\mathrm{VC}=0.168\end{array}$ \\
\hline
\end{tabular}

The results indicate that all of the farmers recognized the high importance of economic benefits, followed by environmental and other benefits, regardless of age. As far as the commercial character of the farm is concerned, the surveyed units were divided into two categories: commercial farms, i.e., those that directed their production to the market, and non-commercial farms. The concordance of answers in both groups concerned only the benefit from RESs, which are the increase in living comfort and reduction in household expenses. Farmers managing commercial farms, as opposed to their counterparts in the alternative group, placed significantly more importance on the economic benefits associated with using green energy for agricultural production, potential opportunities to sell surplus energy (not applicable to prosumer installations), and tax benefits. They also appreciated the importance of the environmental benefits and the opportunity to build their own position and recognition in the local community.

In relation to the agricultural area of farms, differences in farmers' answers occurred in the case of benefits such as the reduction in agricultural production costs. Such a benefit was definitely more often declared by farmers managing relatively larger farms. Farmers in this group also acknowledged the benefit of access to grants or other low-cost sources of financing for RES installations. 
In terms of the direction of agricultural production, the differences concerned the assessment of the importance of two RES benefits, namely environmental benefits and the reduction in agricultural production costs. Farmers managing farms focused on plant or animal production, as well as organic farms and the so-called special branches, attributed greater importance to both types of benefits.

The relationships between the form of VAT taxation of a farm and the importance of tax benefits, access to grants for financing investments in RESs, and increasing the comfort of a farmer's family were noticed. In this case, the first two of these benefits were more often declared by farmers taxed on a general basis (i.e., as entrepreneurs), and benefits related to the quality of life were more often indicated by farmers taxed as so-called flat-rate farmers. This latter tax status is usually adopted by farmers with small holdings that either do not produce goods for sale at all or produce goods predominantly for the self-supply of the farmer's family.

The observed relationships measured with Cramér's V coefficient are not particularly strong, which is due to the multidimensionality of the benefits of RES installations. The strongest relationship was observed between the commercial nature of the farm and the economic benefits and access to RES grants. The results of $\chi^{2}$ testing give rise to a partial acceptance of hypothesis H4. It was confirmed that farmers managing large-scale commercial and more specialized farms attach more importance to the reduction in agricultural production costs resulting from the adoption of solar PV and solar thermal installations.

\section{Summary and Conclusions Remarks}

Over the past few years, the scale of interest in renewable energy technologies in Poland has significantly increased, and the type of green energy projects implemented has changed, mainly towards photovoltaic systems. The increase in investments in solar $\mathrm{PV}$ micro-installations results from the wide spectrum of use of the energy obtained from this source, the increase in micro-installation efficiency, and the growing affordability of this technology. Programs supporting RES investments from public funds are also an important driver, as from 2019 funding started to be more widely available to beneficiaries. As a result, the number of solar PV installations in Poland grew nearly 9 times between 2018 and 2020, and the installation capacity increased 8 times. A significant proportion of solar PV and solar thermal installations are installed on residential or farm buildings in rural areas, including farms. However, it can be estimated that at the end of 2020, only $7.6 \%$ of all farms in Poland had such installations. The potential for the popularization of solar PV and solar thermal installations in agriculture is, therefore, very high; hence, it is worthwhile to conduct research on the factors determining farmers' investments in such systems. Considering the coexistence of household needs and agricultural production needs on a farm, it is also worth examining the factors favoring the increase in energy consumption for farm needs in the structure of total energy consumption.

Numerous authors have studied the drivers of and barriers to farm investment in renewable energy production technologies, often focusing on some specific technology or type of energy. This paper focuses on the characteristics of a farm and farmers, including their attitudes towards the benefits of RESs. Such studies were also conducted by other authors $[50,52,54]$ but were focused on the determinants of renewable energy installations for the purposes of agricultural production. This article analyzes the factors that influence the adoption of RES installations by farmers, both for the needs of agricultural production and for the needs of the household. The research covered a region with fragmented agriculture, where most farming families combine farm income with income from nonagricultural sources. As a result, the RES installation is equally important to meet the living needs of the farmer's family and to reduce the costs of energy consumption in agricultural production. Research in this context is rare; hence, the article fills a gap in the literature.

The research conducted in the Podkarpackie region shows that farmers' decisions to invest in RESs are conditioned by many factors. Among these, economic benefits, including savings on energy costs and access to favorable sources of investment financing (mainly 
grants), as well as the possibility of tax breaks, play the most important role. Rising energy prices and increasing energy demand in agriculture, which are also linked to climate change, are also important for farmers. The increasing efficiency and performance of modern installations is a strong incentive for farmers to adopt solar PV and solar thermal systems. Farmers who already have RES installations and those who have benefited from RES grants are more likely to express interest in further RES installations. Research results in this area are consistent with research conducted in other countries [31,42,48].

Studies have shown that in the case of agricultural holdings, a significant part of the energy obtained from RESs is still used for the farmers' household needs. Less than $60 \%$ of solar PV installations and only $15.5 \%$ of solar thermal installations are used for agricultural production purposes. The share of agricultural production in total energy consumption from RESs rises with an increase in the area of an agricultural holding and is higher in the case of targeted or specialized farms as compared to mixed-production farms.

Farmers see many benefits from using RES installations for generating energy on their farms. These relate most to economic aspects such as cost savings, energy independence, and protection against the risk of soaring energy prices. Furthermore, farmers also point to environmental benefits, which demonstrates their high environmental awareness. The reputational benefits of having RESs are the least important for farmers.

This paper has found that there is no relationship between the farmer's age and recognizing different benefits of generating energy using solar PV and solar thermal systems. However, younger farmers are more likely to make such investments and make greater use of the generated energy for agricultural production. This conclusion is consistent with the results of research by other authors conducted, e.g., in the United States and Europe [49,51-54].

Investments in solar PV and solar thermal systems are more likely to be made on larger, commercial, and specialized farms. At the same time, the key rationale behind RES investments for farmers managing such farms is the rate of return on investment determined by the reduction in energy expenses and obtaining non-refundable sources of financing. Environmental and social considerations are of secondary importance, which does not mean that their role will not increase.

The results of the research can serve economic policy in the context of the implementation of instruments to support the adoption of PV and solar technologies in agriculture, especially those adapted to the specificity of agriculture with a fragmented agrarian structure. This issue is important both for the sustainable development of agriculture and for the implementation of environmental and climate objectives expected from the energy transition in Poland. Agricultural areas and rural areas in general are an important part of this transformation. Potential directions of future research should focus on the analysis of behavioral and social conditions for the active participation of farmers in the creation of local energy communities.

Author Contributions: Conceptualization, R.K. and M.L.; methodology, R.K. and K.C.; software, S.D. and R.P.; validation, R.K., S.D. and R.P.; formal analysis, M.L. and R.K.; investigation, M.L. and R.P.; resources, K.C. and S.D.; data curation, K.C.; writing-original draft preparation, R.K.; writingreview and editing, R.K.; visualization, R.P.; supervision, R.K.; project administration, K.C.; funding acquisition, R.K. All authors have read and agreed to the published version of the manuscript.

Funding: This research was funded by the Institute of Economics and Finance, University of Rzeszów.

Institutional Review Board Statement: Not applicable.

Informed Consent Statement: Not applicable.

Data Availability Statement: Not applicable.

Conflicts of Interest: The authors declare no conflict of interest. 


\section{References}

1. Akella, A.K.; Saini, R.P.; Sharma, M.P. Social, economical and environmental impacts of renewable energy systems. Renew. Energy 2009, 34, 390-396. [CrossRef]

2. Piwowar, A.; Dzikuć, M. Development of renewable energy sources in the context of threats resulting from low-altitude emissions in rural areas in Poland: A review. Energies 2019, 12, 3558. [CrossRef]

3. Klepacka, A.M.; Florkowski, W.J.; Menga, T. Clean, accessible, and cost-saving: Reasons for rural household investment in solar panels in Poland. Resour. Conserv. Recycl. 2018, 139, 338-350. [CrossRef]

4. Briguglioa, M.; Formosaa, G. When households go solar: Determinants of uptake of a Photovoltaic Scheme and policy insights. Energy Policy 2017, 108, 154-162. [CrossRef]

5. Kaya, O.; Klepacka, A.M.; Florkowski, J.W. Achieving renewable energy, climate, and air quality policy goals: Rural residential investment in solar panel. J. Environ. Manag. 2019, 248, 109309. [CrossRef]

6. Choi, C.S.; Siregar, I.Z.; Ravi, S. Reframing the Competition for Land between Food and Energy Production in Indonesia. In Land Cover and Land Use Change on Islands, Social \& Ecological Threats to Sustainability; Walsh, S.J., Riveros-Iregui, D., Arce-Nazario, J., Page, P.H., Eds.; Springer International Publishing: New York, NY, USA, 2020; pp. 241-260.

7. Gradziuk, P.; Gradziuk, B. Renewable Energy Sources as a Development Opportunity for Peripheral Areas. Econ. Reg. Stud. 2020, 13, 184-198. [CrossRef]

8. Council of the European Union; European Parliament. Directive (EU) 2018/2001 of the European Parliament and of the Council of 11 December 2018 on the promotion of the use of energy from renewable sources. Off. J. Eur. Union 2018, L 328, 82-209.

9. Ustawa z dnia 20 lutego 2015 r. o odnawialnych źródłach energii. Dz. U. 2015 poz. 478 (Z późniejszymi zmianami).

10. Wiśniewski, G.; Michałowska-Knap, K.; Oniszk-Popławska, A.; Więcka, A.; Dziamski, P.; Kamińska, M.; Curkowski, A. Określenie Potencjatu Energetycznego Regionów Polski w Zakresie Odnawialnych Źródeł Energii-Wnioski dla Regionalnych Programów Operacyjnych na Okres Programowania 2014-2020; Ministerstwo Rozwoju Regionalnego: Warszawa, Polska, 2011.

11. Fu, R.; Feldman, D.; Margolis, R.; Woodhouse, M.; Ardani, K.U.S. Solar Photovoltaic System Cost Benchmark, Q1 2017; National Renewable Energy Laboratory: Golden, CO, USA, 2017.

12. Gradziuk, P.; Gradziuk, B.; Us, A. Tendencje kształtowania się kosztów inwestycyjnych w sektorze fotowoltaicznym. Roczniki 2018, 2018, 44-49. [CrossRef]

13. Rynek Fotowoltaiki w Polsce; Instytut Energetyki Odnawialnej: Warszawa, Polska, 2019.

14. Ciechomska, A. Wymiar wsparcia wykorzystania odnawialnych źródeł energii w ramach RPO Województwa Mazowieckiego w perspektywie 2007-2013. Rocz. Nauk. Stowarzyszenia Ekon. Rol. Agrobiz. 2018, 2018, 29-34.

15. Gradziuk, P.; Gradziuk, B. Próba oceny absorpcji środków z funduszy europejskich na rozwój wykorzystania odnawialnych źródeł energii w woj. lubelskim. Rocz. Nauk. Ekon. Rol. Rozw. Obsz. Wiej. 2017, 104, 95-105.

16. Kossowski, T. Regionalne programy operacyjne jako czynnik stymulujaccy wykorzystanie odnawialnych źródeł energii. Roczniki 2016, 2016, 86-92.

17. Wazed, S.M.; Hughes, B.R.; O'Connor, D.; Kaiser, J.; Calautit, J. Solar Driven Irrigation Systems for Remote Rural Farms. Energy Procedia 2017, 142, 184-191. [CrossRef]

18. Schmitter, P.; Kibret, K.S.; Lefore, N.; Barron, J. Suitability mapping framework for solar photovoltaic pumps for smallholder farmers in sub-Saharan Africa. Appl. Geogr. 2018, 94, 41-57. [CrossRef]

19. Fieducik, J.; Godlewski, J. Ekonomiczne i środowiskowe aspekty skoncentrowanej fotowoltaiki. Prz. Elektrotechniczny 2015, 9, 24-26. [CrossRef]

20. Standar, A.; Kozera, A.; Satoła, Ł. The Importance of Local Investments Co-Financed by the European Union in the Field of Renewable Energy Sources in Rural Areas of Poland. Energies 2021, 14, 450. [CrossRef]

21. Chodkowska-Miszczuk, J. Odnawialne źródła energii i ich wykorzystanie jako nowe trendy na obszarach wiejskich w Polsce. Studia Obsz. Wiej. 2014, 35, 227-241.

22. Malinowski, M.; Leon, J.I.; Abu-Rub, H. Solar Photovoltaic and Thermal Energy Systems: Current Technology and Future Trends. Proc. IEEE 2017, 105, 2132-2146. [CrossRef]

23. Niechaj, M. Effective use of photovoltaic systems in polish conditions. J. Ecol. Eng. 2016, 17, 147-154. [CrossRef]

24. Halamska, M. Specyfika rolnictwa rodzinnego w Polsce: Ciężar przeszłości i obecne uwarunkowania. Wieś Rol. 2015, 166, 107-129.

25. Kryszak, Ł. Selected problems of agricultural income accounts. Rocz. Nauk. Stowarzyszenia Ekon. Rol. Agrobiz. 2017, XIX, 168-173. [CrossRef]

26. Labay, D.G.; Kinnear, T.C. Exploring the consumer decision process in the adoption of solar energy systems. J. Consum. Res. 1981, 8, 271-278. [CrossRef]

27. Sidiras, D.K.; Koukios, E.G. Solar system diffusion in local markets. Energy Policy 2004, 32, 2007-2018. [CrossRef]

28. Faiers, A.; Neame, C. Consumer attitudes towards domestic solar power systems. Energy Policy 2006, 34, 1797-1806. [CrossRef]

29. Bollinger, B.; Gillingham, K. Peer effects in the diffusion of solar photovoltaic panels. Mark. Sci. 2012, 31, 900-912. [CrossRef]

30. Zhai, P.; Williams, E.D. Analyzing consumer acceptance of photovoltaics (PV) using fuzzy logic model. Renew. Energy 2012, 41, 350-357. [CrossRef]

31. Fleiß, E.; Hatzl, S.; Seebauer, S.; Posch, A. Money, not morale: The impact of desires and beliefs on private investment in photovoltaic citizen participation initiatives. J. Clean. Prod. 2017, 141, 920-927. [CrossRef] 
32. Alipour, M.; Salim, H.; Stewart, R.A.; Sahin, O. Residential solar photovoltaic adoption behaviour: End-to-end review of theories, methods and approaches. Renew. Energy 2021, 170, 471-486. [CrossRef]

33. Jäger-Waldau, A. Snapshot of Photovoltaics-February 2020. Energies 2020, 13, 930. [CrossRef]

34. Jäger-Waldau, A. The Untapped Area Potential for Photovoltaic Power in the European Union. Clean Technol. 2020, 2, 440-446. [CrossRef]

35. Wustenhagen, R.; Bilharz, M. Green energy market development in Germany effective public policy and emerging customer demand. Energy Policy 2006, 34, 1681-1696. [CrossRef]

36. Guidolin, M.; Mortarino, C. Cross-country diffusion of photovoltaic systems: Modelling choices and forecasts for national adoption patterns. Technol. Forecast. Soc. Chang. 2010, 77, 279-296. [CrossRef]

37. Kwan, C.L. Influence of local environmental, social, economic and political variables on the spatial distribution of residential solar PV arrays across the United States. Energy Policy 2012, 47, 332-344. [CrossRef]

38. Cherrington, R.; Goodship, V.; Longfield, A.; Kirwan, K. The feed-in tariff in the UK: A case study focus on domestic photovoltaic systems. Renew. Energy 2013, 50, 421-426. [CrossRef]

39. Jenner, S.; Groba, F.; Indvik, J. Assessing the strength and effectiveness of renewable electricity feed-in-tariffs in European Union countries. Energy Policy 2013, 52, 385-401. [CrossRef]

40. Bauner, C.; Crago, C.L. Adoption of residential solar power under uncertainty: Implications for renewable energy incentives. Energy Policy 2015, 86, 27-35. [CrossRef]

41. Chodkowska-Miszczuk, J.; Szymańska, D. Update of the review: Cultivation of energy crops in Poland against socio-demographic factors. Renew. Sustain. Energy Rev. 2011, 15, 4242-4247. [CrossRef]

42. Brudermann, T.; Reinsberger, K.; Orthofer, A.; Kislinger, M.; Posch, A. Photovoltaics in agriculture: A case study on decision making of farmers. Energy Policy 2013, 61, 96-103. [CrossRef]

43. Bakundukize, A.; Twizerimana, M.; Bernadette, D.; Bizabakoraho, J.P.; Nsekambabaye, T. Design and Modelling of PV Power Plant for Rural Electrification in Kayonza, Rwanda. J. Energy Res. Rev. 2021, 7, 31-55. [CrossRef]

44. Irfan, M.; Yadav, S.; Shaw, K. The adoption of solar photovoltaic technology among Indian households: Examining the influence of entrepreneurship. Technol. Forecast. Soc. Chang. 2021, 169, 120815. [CrossRef]

45. Jager, W. Stimulating the diffusion of photovoltaic systems: A behavioural perspective. Energy Policy 2006, 34, 1935-1943. [CrossRef]

46. Owens, S.; Driffill, L. How to change attitudes and behaviours in the context of energy. Energy Policy 2008, 36, 4412-4418. [CrossRef]

47. Islam, T.; Meade, N. The impact of attribute preferences on adoption timing: The case of photo-voltaic (PV) solar cells for household electricity generation. Energy Policy 2013, 55, 521-530. [CrossRef]

48. Fokaides, P.A.; Kylili, A. Towards grid parity in insular energy systems: The case of photovoltaics (PV) in Cyprus. Energy Policy 2014, 65, 223-228. [CrossRef]

49. Beckman, J.; Xiarchos, I.M. Why are Californian farmers adopting more (and larger) renewable energy operations? Renew. Energy 2013, 55, 322-330. [CrossRef]

50. Ge, J.; Sutherland, L.-A.; Polhill, J.G.; Matthews, K.; Miller, D.; Wardell-Johnson, D. Exploring factors affecting on-farm renewable energy adoption in Scotland using large-scale microdata. Energy Policy 2017, 107, 548-560. [CrossRef]

51. Jensen, K.; Clark, C.; Ellis, P.; English, B.; Menard, J.; Walsh, M.; de la Torre-Ugarte, D. Farmer willingness to grow switchgrass for energy production. Biomass Bioenergy 2007, 31, 773-781. [CrossRef]

52. Tate, G.; Mbzibain, A.; Ali, S.A. comparison of the drivers influencing farmers' adoption of enterprises associated with renewable energy. Energy Policy 2012, 49, 400-409. [CrossRef]

53. Borchers, A.M.; Xiarchos, I.; Beckman, J. Determinants of wind and solar energy system adoption by U.S. farms: A multilevel modeling approach. Energy Policy 2014, 69, 106-115. [CrossRef]

54. Sutherland, L.A.; Toma, L.; Barnes, A.P.; Matthews, K.B.; Hopkins, J. Agri-environmental diversification: Linking environmental, forestry and renewable energy engagement on Scottish farms. J. Rural Stud. 2016, 47, 10-20. [CrossRef]

55. Welsch, H.; Kühling, J. Determinants of pro-environmental consumption: The role of reference groups and routine behavior. Ecol. Econ. 2009, 69, 166-176. [CrossRef]

56. Sutherland, L.A.; Holstead, K.L. Future-proofing the farm: On-farm wind turbine development in farm business decision-making. Land Use Policy 2014, 36, 102-112. [CrossRef]

57. Reise, C.; Musshoff, R.; Granoszewski, K.; Spiller, A. Which factors influence the expansion of bioenergy? An empirical study of the investment behaviours of German farmers. Ecol. Econ. 2012, 73, 133-141. [CrossRef]

58. Shi, L.; Zhou, W.; Kriström, B. Residential demand for green electricity. Environ. Econ. 2013, 4, 39-50.

59. Bartolini, F.; Viaggi, D. An analysis of policy scenario effects on the adoption of energy production on the farm: A case study in Emilia-Romagna (Italy). Energy Policy 2012, 51, 454-464. [CrossRef]

60. Ruiz-Fuensanta, M.J.; Gutiérrez-Pedrero, M.J.; Tarancón, M.A. The Role of Regional Determinants in the Deployment of Renewable Energy in Farms. The Case of Spain. Sustainability 2019, 11, 5937. [CrossRef]

61. Schaffer, A.; Düvelmeyer, C. Regional drivers of on-farm energy production in Bavaria. Energy Policy 2016, 95, 361-369. [CrossRef]

62. Walsh, M. Energy tax credits and housing improvements. Energy Econ. 1989, 11, 275-284. [CrossRef]

63. Poortinga, W.; Steg, L.; Vleg, C.; Wiesma, G. Household preference for energy saving measures: A conjoint analysis. J. Econ. Psychol. 2003, 24, 49-64. [CrossRef]

64. Meade, N.; Islam, T. Modelling and forecasting the diffusionof innovation-A 25 year review. Int. J. Forecast. 2006, 22, 519-545. [CrossRef]

65. Kim, K.-K.; Lee, C.-G. Evaluation and optimization of feed-in-tariffs. Energy Policy 2012, 49, 129-203. [CrossRef] 
66. Mój Prąd Może Ruszyć od 1 Lipca. Available online: https:/ /www.rynekelektryczny.pl/stan-programu-moj-prad/ (accessed on 20 May 2021).

67. Olczak, P.; Kryzia, D.; Matuszewska, D.; Kuta, M. “My Electricity” Program Effectiveness Supporting the Development of PV Installation in Poland. Energies 2021, 14, 231. [CrossRef]

68. Iwaszczuk, N.; Trela, M. Analysis of the Impact of the Assumed Moment of Meeting Total Energy Demand on the Profitability of Photovoltaic Installations for Households in Poland. Energies 2021, 14, 1637. [CrossRef]

69. Czyste Powietrze w Liczbach. Available online: https: / / czystepowietrze.gov.pl (accessed on 20 May 2021).

70. European Commission. 2020: State of the Union: Commission Raises Climate Ambition and Proposes 55\% Cut in Emissions by 2030. Available online: https:/ / ec.europa.eu/commission/presscorner/detail/en/IP_20_1599 (accessed on 16 March 2021).

71. Ministerstwo Aktywów Państwowych. National Energy and Climate Plan for the Years 2021-2030 (Krajowy Plan na Rzecz Energii $i$ Klimatu na Lata 2021-2030. Założenia i Cele Oraz Polityki i Działania); Ministerstwo Aktywów Państwowych: Warszawa, Polska, 18 December 2019.

72. Council of the European Union; European Parliament. Directive 2009/28/EC of the European Parliament and of the Council of 23 April 2009 on the promotion of the use of energy from renewable sources and amending and subsequently repealing Directives 2001/77/EC and 2003/30/EC. Off. J. Eur. Union 2009, L 140, 16-62.

73. Energia ze Źródet Odnawialnych w 2018 r.; Central Statistical Office (GUS): Warszawa, Poland, 2019.

74. EEA. Air Quality in Europe-2015 Report. Raport Europejskiej Agencji Środowiska (EEA). 2015. Available online: http: / / www.eea.europa.eu/ / publications / air-quality-in-europe-2015 (accessed on 9 January 2021).

75. Liu, W.L.; Spaargaren, G.; Heerink, N.; Mol, A.P.J.; Wang, C. Energy consumption practices of rural households in north China: Basic characteristics and potential for low carbon development. Energy Policy 2013, 55, 128-138. [CrossRef]

76. Gosens, J.; Lu, Y.L.; He, G.Z.; Bluemling, B.; Beckers, T.A.M. Sustainability effects of household-scale biogas in rural China. Energy Policy 2013, 54, 273-287. [CrossRef]

77. Li, X.; Li, H.; Wang, X. Farmers' willingness to convert traditional houses to solar houses in rural areas: A survey of 465 households in Chongqing, China. Energy Policy 2013, 63, 882-886. [CrossRef]

78. Maddala, G.S. Ekonometria; Wydawnictwo Naukowe PWN: Warszawa, Poland, 2008; p. 372.

79. Cramer, J.S. The early origins of the logit model. Stud. Hist. Philos. Sci. Part C 2004, 35, 613-626. [CrossRef]

80. Welfe, A. Ekonometria. METODY i Ich Zastosowanie; PWE: Warszawa, Poland, 2009.

81. Kot, S.M.; Jakubowski, J.; Sokołowski, A. Statystyka; Difin: Warszawa, Poland, 2011; pp. 293-295.

82. Pułaska-Turyna, B. Statystyka Dla Ekonomistów; Difin: Warszawa, Poland, 2008; pp. 284-285.

83. Lechwar, M. Analysis of Potential of Renewable Energy Sources in the PL-UA Cross-Border Region, [w:] Practical Guide to RES Development with Examples of Good Practices; Regional Development Agency: Rzeszow, Poland, 2014.

84. Czyżewski, A.; Kata, R.; Matuszczak, A. Wpływ Wydatków Budżetowych na Zmiany Strukturalne i Dochody w Rolnictwie w Warunkach Funkcjonowania w Polsce Instrumentów WPR. Ekonomista 2020, 6, 781-811.

85. Raport Zawierajacy Zbiorcze Informacje Dotyczace Energii Elektrycznej Wytworzonej z Odnawialnego Źródła Energii w Mikroinstalacji (w Tym Przez Prosumentów) i Wprowadzonej do Sieci Dystrybucyjnej w 2020 r.; Urząd Regulacji Energetyki: Warszawa, Polska, 2021.

86. Strategia Zrównoważonego Rozwoju Wsi, Rolnictwa i Rybactwa 2030; Ministerstwo Rolnictwa i Rozwoju Wsi: Warszawa, Polska, 2019.

87. Ogłoszenie Prezesa Agencji Restrukturyzacji i Modernizacji Rolnictwa z Dnia 16 Września 2020 r. w Sprawie Wielkości Średniej Powierzchni Gruntów Rolnych w Gospodarstwie Rolnym w Poszczególnych Województwach, ARiMR. Available online: https: / / www.arimr.gov.pl/pomoc-krajowa/srednia-powierzchnia-gospodarstwa.html (accessed on 16 March 2021). 